
ISSN : 2615-1995, E-ISSN : 2615-0654

J. Madani., Vol. 3, No. 1, Maret 2020 (104 - 117)

(C)2018 Lembaga Kajian Demokrasi

dan Pemberdayaan Masyarakat (LKD-PM)

DOI : https://doi.org/10.33753/madani.v3i1.89

\title{
Tinjauan Maqashid Al-Syariah Terhadap Perlindungan Jiwa Dalam Pergub Sumsel Nomor 6 Tahun 2017 Tentang Perlindungan Anak Yatim
}

\author{
Ahmad Yani Nasution \\ Fakultas Ekonomi, Universitas Pamulang \\ dosen01583@unpam.ac.id
}

\begin{abstract}
Abstrak
Penelitian ini berjudul "Tinjauan Maqashid Al-Syariah Terhadap Perlindungan Jiwa Anak Yatim dalam Pergub Sumsel Nomor 6 Tahun 2017 Tentang Perlindungan Anak Yatim”. Tujuan dari penelitian ini adalah pertama untuk mengetahui bagaimana perlindungan jiwa dalam Pergub Sumsel Nomor 6 Tahun 2017 tentang Perlindungan Anak Yatim. Kedua untuk mengetahui bagaimana tinjauan Maqashid Al-Syariah terhadap perlindungan jiwa dalam Pergub Sumsel Nomor 6 Tahun 2017 tentang Perlindungan Anak Yatim. Dalam penelitian ini penulis menggunakan teknik analisis deskriptif, yaitu berusaha mengambarkan secara umum tentang upaya perlindungan jiwa terhadap anak yatim dalam Peraturan Pemerintah Daerah Sumatera Selatan No 6 Tahun 2017 tentang anak yatim, yang ditinjau dari Maqashid as-Syariah dari data sekunder yang berupa buku-buku, hasil karya ilmia para sarjana, hasil-hasil penelitian, artikel, jurnal dan dokumen-dokumen yang mendukung penelitian ini, dengan cara demikian pembaca akan mendapatkan hasil penelitian tentang perlindungan jiwa anak yatim dalam pergub sumsel tentang perlindungan anak yatim. Setelah menganalisa pergub sumsel nomor 6 tahun 2017 akhirnya penulis mendapat kesimpulan bahwa dalam pergub tersebut terdapat pokok maqashid syariah yaitu hifz nafs. (memelihara jiwa).
\end{abstract}

Kata Kunci : Anak Yatim, Maqashid Syariah, Pergub Sumsel

\begin{abstract}
This study is entitled "A Review of Maqashid Al-Shariah Against the Protection of Orphans' Mental Life in the North Sumatra Governor Regulation No. 6 of 2017 Regarding Orphan Protection". The purpose of this study is First To find out how the protection of life in the Governor of South Sumatra No. 6 of 2017 concerning Protection of Orphans. Second To find out how Maqashid al-Syariah review of life protection in the Governor of South Sumatra No. 6 of 2017 concerning Protection of Orphans. In this study the authors used a descriptive analysis technique, which seeks to describe in general the efforts to protect the lives of orphans in South Sumatra local government regulation no 6 of 2017 concerning orphans, as viewed from Maqashid as-Syariah from secondary data in the form of books, scientific work of scholars, research results, articles, journals and documents that support this research. In this way the reader will get the results of research on the protection of the lives of orphans in the summit regulation regarding the protection of orphans. After analyzing the Governor's Regulation No. 6 of 2017 the author finally came to the conclusion that in the Governor's Regulation there is the principal of Maqashid Shari'ah, the Hifz Nafs. (preserving the soul).
\end{abstract}

Keywords: Orphans, Maqashid Shari'ah, Pergub Sumsel

\section{PENDAHULUAN}

Penelitian ini memfokuskan pada Tinjauan
Maqashid Al-Syariah terhadap Perlindungan Jiwa Anak Yatim dalam Pergub Sumsel Nomor 6 Tahun 
2017 tentang Perlindungan Anak Yatim. Negara Indonesia adalah negara yang memberikan perlindungan bagi setiap warga didalamnya tanpa terkecuali termasuk anak-anak yatim. Salah satu usaha konkrit yang dilakukan oleh pemerintah daerah Sumatera Selatan dengan mengeluarkan Undang-Undang tentang perlindungan anak yatim dalam Pergub Sumsel nomor 6 tahun 2017 tentang perlindungan anak yatim. Hal tersebut dilakukan sebagai tindakan nyata dan penguatan terhadap adanya perlindungan anak-anak yatim. Sehingga dengan demikian anak yatim bebas dari diskriminasi dan tindakan lainnya yang tidak layak mereka dapatkan sebagai seorang anak.

Berbagai gambaran mengenai kondisi anakanak yatim yang mengalami berbagai kasus yang tidak manusiawi. Salah satunya ialah kasus yang dikutip dari republika.co.id tanggal 24 Februari 2014 (Syahputra, 2014) adanya enam anak dari panti asuhan Yayasan Kasih Sayang Bunda atas dugaan penganiayaan dan penelantaran di Tangerang. Penganiayaan tersebut berupa pemukulan menggunakan sapu, gesper, selang, dan hanya diberi makanan berupa mie instan. Hal ini terungkap ketika salah satu donatur melihat anak yang tidak terurus, kurus, dan sempat menemukan luka pada sejumlah bagian tubuh anak.

Sumatera Selatan menjadi provinsi pertama yang memiliki perda perlindungan anak yatim. Disahkannya perda ini akan ada regulasi yang jelas tentang perlindungan anak yatim. Sehingga apabila terdapat pelanggaran akan dapat dikenai sanksi hukum. Seperti keberadaan panti asuhan yang disinyalir memiliki tujuan mencari keuntungan sepihak saja, pelaku kekerasan, ataupun pelanggaran-pelanggaran lainnya terhadap perlindungan jiwa anak yatim. Melihat hal tersebut, penulis tertarik untuk membahas tentang "Tinjauan Maqashid al-Syariah Terhadap Perlindungan Jiwa Anak Yatim dalam Pergub Sumsel Nomor 6 Tahun 2017 tentang Perlindungan Anak Yatim".

Pada penelitian sebelumnya, Lapili Fukar (2017) dengan judul "Tinjauan Maqashid Asy - Syariah Terhadap Perlindungan Jiwa Dalam Undang-Undang Nomor 8 Tahun 2016 Tentang Penyandang Disabilitas". Dalam penelitian ini dibahas mengenai perlindungan jiwa terhadap penyandang disabilitas yang kerap mendapat tindakan pelanggaran terhadap perlindungan jiwa mereka.

Adapun tujuan dari penelitian ini adalah pertama untuk mengetahui bagaimana perlindungan jiwa dalam Pergub Sumsel Nomor 6 Tahun 2017 tentang Perlindungan Anak Yatim. Kedua untuk mengetahui bagaimana tinjauan Maqashid al-Syriah terhadap perlindungan jiwa dalam Pergub Sumsel Nomor 6 Tahun 2017 tentang Perlindungan Anak Yatim.

\section{METODE}

Dalam sebuah penelitian, Metode merupakan satu hal yang sangat penting. sebab cara kerja dalam mekanisme sebuah penelitian ditentukan oleh apa metode yang dipakai oleh peneliti. Inilah yang menyebabkan penulis memakai metode jenis pustaka (library researce). Pengkajian buku-buku atau hasil karya ilmiah lainnya merupakan proses yang harus dilakukan untuk menemukan hasil dari sebuah penilitian ini. Istilah lain dari penelitian ini adalah library research. Adapun proses yang dilakukan adalah dengan menggunakan data sekunder yaitu pengumpulan buku-buku, dokumen-dokumen, peraturan-peraturan, hasil penelitian, arsip kemudian dianalisis untuk mendapatkan hasil penelitian. Penelitian ini mengambil sumber data dari salah satu Peraturan Pemerintah Daerah yaitu peraturan Gubernur Sumatera Selatan tentang penyelenggaraan perlindungan anak dan beberapa Undang-undang yang berkaitan sebagai pelengkap. Bahan Hukum Sekunder adalah data yang diperoleh dari buku-buku ushul fiqih, pendamping hasil karya ilmia para sarjana, hasilhasil penelitian, artikel, jurnal dan dokumendokumen yang berhubungan dengan penelitian ini. Dalam penelitian ini, teknik pengumpulan data adalah menginventarisasi buku-buku yang berkaitan dengan penelitian. Salah satunya buku-buku ushul fiqih dan peraturan-peraturan yang mengenai perlindungan anak yatim dalam peraturan Gubernur Sumatera Selatan tentang perlindungan anak yatim, kemudian menandai 
pasal-pasal yang mengatur tentang perlindungan jiwa terhadap perlindungan anak yatim serta bahan-bahan literatur yang berhubungan dengan judul yang diteliti. Setelah semua terkumpul barulah penulis menelaah kembali semua peraturan-peraturan untuk mencari kesesuaian dengan masalah yang akan diteliti. Dalam penelitian ini penulis mengunakan teknik analisis deskriptif, yaitu berusaha mengambarkan secara umum tentang upaya perlindungan jiwa terhadap anak yatim dalam Peraturan pemerintah daerah Sumatera Selatan No 6 Tahun 2017 Tentang anak yatim, yang ditinjau dari Maqashid as-Syariah dari data sekunder yang berupa buku-buku, hasil karya ilmiah para sarjana, hasil-hasil penelitian, artikel, jurnal dan dokumen-dokumen yang mendukung penelitian ini

\section{HASIL dan PEMBAHASAN}

A. Perlindungan Jiwa dalam Pergub nomor 6 tahun 2017 Tentang Perlindungan Anak Yatim

Disahkannya Pergub Nomor 6 Tahun 2017 Tentang Perlindungan anak yatim menunjukkan komitmen dan kesungguhan pemerintah untuk menghormati, melindungi dan memenuhi kebutuhan anak yatim.

Pada BAB I berisi ketentuan umum terdiri dari satu Pasal yang berisi tentang Peraturan Daerah. Adapun yang dimaksud adalah sebagai berikut:

1. Provinsi adalah Provinsi Sumatera Selatan.

2. Pemerintah Provinsi adalah kepala daerah sebagai unsur penyelenggara Pemerintahan Daerah yang memimpin pelaksanaan urusan pemerintahan yang menjadi kewenangan daerah otonom.

3. Pemerintahan Provinsi adalah penyelenggaraan urusan pemerintahan oleh Pemerintah Daerah dan Dewan Perwakilan Rakyat Daerah menurut asas otonomi dan tugas pembantuan dengan prinsip otonomi seluas-luasnya dalam sistem dan prinsip Negara Kesatuan Republik Indonesia sebagaimana dimaksud dalam Undang-Undang Dasar Negara Republik Indonesia Tahun 1945.

4. Gubernur adalah Gubernur Provinsi Sumatera Selatan.

5. Dewan Perwakilan Rakyat Daerah yang selanjutnya disingkat DPRD adalah lembaga perwakilan rakyat daerah yang berkedudukan sebagai unsur penyelenggara Pemerintahan Daerah

6. Organisasi Perangkat Daerah yang selanjutnya disingkat OPD adalah Organisasi Perangkat Daerah Provinsi Sumatera Selatan yang tugas pokok dan fungginya di bidang sosial dan kesejahteraan.

7. Lembaga Kesejahteman Soaial Anak adalah lembaga-lembaga yang dibentuk oleh Pemerintah, Pemerintah Provinsi dan Masyarakat dalam menyelenggarakan pengasuhan anak.

8. Perlindungan Anak Yatim, Anak Yatim Piatu dan Kaum Dhuafa adalah kondisi terpenuhinya kebutuhan material, spiritual, pendidikan, kesehatan dan sosial anak yatim, anak yatim piatu, dan kaum dhuafa agar dapat hidup layak dan mampu mengembangkan diri, sehingga dapat melaksanakan fungsi sosialnya.

9. Penyelenggaraan Perlindungan Anak Yatim, Anak Yatim Piatu, dan Kaum Dhuafa adalah upaya yang terarah, terpadu, dan berkelanjutan yang dilakukan Pemerintah, Pemerintah Daerah dan masyarakat dalam bentuk pelayanan sosial dan hukum guna memenuhi kebutuhan dasar setiap anak yatim, anak yatim piatu, dan kaum dhuafa, yang meliputi rehabilitasi sosial, jaminan kesehatan, jaminan sosial, dan perlindungan hukum.

10. Jaminan Pendidikan adalah skema yang melembaga untuk menjamin seluruh anak yatim, anak yatim piatu, dan kaum dhuafa agar dapat memenuhi kebutuhan dasar pendidikan yang layak.

11. Jaminan Kesehatan adalah skema yang melembaga untuk menjamin seluruh 
anak yatim, anak yatim piatu, dan kaum dhuafa agar dapat memenuhi kebutuhan dasar kesehatan yang layak.

12. Jaminan Sosial adalah skema yang melembaga untuk menjamin seluruh anak yatim, anak yatim piatu, dan kaum dhuafa agar dapat memenuhi kebutuhan dasar hidup yang layak.

13. Perlindungan Hukum adalah semua upaya yang diarahkan untuk mencegah dan menangani risiko hukum.

14. Perlindungan Sosial adalah semua upaya yang diarahkan untuk mencegah dan menangani resiko dari guncangan dan kerentanan sosial.

15. Anak adalah seseorang yang belum berusia 18 (delapan belas) tahun termasuk anak yang masih dalam kandungan.

16. Orang tua adalah ayah dan/atau ibu kandung, atau ayah dan/atau ibu tiri, atau ayah dan/atau ibu angkat.

17. Wali adalah orang atau badan yang menjalankan kekuasaan asuh sebagai orang tua terhadap anak.

18. Perwalian adalah kewenangan untuk melaksanakan perbuatan hukum demi kepentingan, atau atas nama, anak yang orang tuanya telah meninggal, atau tidak mampu melakukan perbuatan hukum.

19. Anak Yatim adalah anak yang ditinggal bapak kandungnya karena kematian.

20. Anak yatim piatu adalah anak yang ditinggal bapak dan ibu kandungnya karena kematian.

21. Kaum Dhuafa adalah orang yang sama sekali tidak mempunyai sumber mata pencaharian dan/atau mempunyai sumber mata pencaharian tetapi tidak mempunyai kemampuan memenuhi kebutuhan dasar yang layak bagi kehidupan dirinya dan/atau keluarganya.

22. Keluarga adalah unit terkecil dalam masyarakat yang terdiri dari suami/istri, atau suami/istri dan anaknya, atau ayah dan anaknya, atau ibu dan anaknya, atau keluarga sedarah dalam garis lurus keatas atau kebawah sampai dengan derajat ketiga.

23. Kekerasan Dalam Rumah Tangga adalah setiap perbuatan terhadap seseorang yang berakibat timbulnya kesengsaraan atau penderitaaan secara fisik, seksual, psikologi, dan atau penelantaran rumah tangga termasuk ancaman untuk melakukan perbuatan, pemaksaan, atau perampasan kemerdekaan secara melawan hukum dalam lingkup rumah tangga.

24. Masyarakat adalah penduduk yang berdomisili di Provinsi yang dibuktikan dengan Kartu Tanda Penduduk dan/ atau bentuk keterangan kependudukan lainnya yang disahkan oleh Kepala Desa/ Lurah dan Camat.

Kemudian BAB II berisi Asas Fungsi Dan Tujuan yaitu:

Pasal 2 Penyelenggaraan perlindungan anak yatim, anak yatim piatu dan kaum dhuafa di Provinsi dilaksanakan berdasarkan asas:

a. Kesetiakawanan dan kasih sayang;

b. Keadilan;

c. Kemanfaatan;

d. Keterpaduan;

e. Kemitraan;

f. Keterbukaan;

g. Akuntabilitas;

h. Partisipasi;

i. Profesionalitas dan

j. Berkelanjutan

Pasal 3 Fungsi penyelenggaraan perlindungan anak yatim, anak yatim piatu, dan kaum dhuafa meliputi:

a. sosial;

b. kemandirian;

c. pengembangan potensi; dan

d. kepastian hukum.

Pasal 4 Penyelenggaraan perlindungan anak yatim, anak yatim piatu, dan kaum dhuafa bertujuan:

a. Memberikan perlindungan dari eksploitasi, berupa eksploitasi seksual, kerja paksa, perlibatan dalam kegiatan po- 
litik, perbudakan, pengambilan dan/ atau penjualan organ tubuh guna mendapatkan keuntungan pribadi atau kelompok;

b. Meningkatkan taraf kesejahteraan, kualitas, dan kelangsungan hidup;

c. Mencegah permasalahan sosial;

d. Menyembuhkan seseorang atau individu yang mengalami permasalahan sosial;

e. Memulihkan fungsi sosial dalam rangka mencapai kemandirian;

f. Meningkatkan ketahanan sosial dalam mencegah dan menangani masalah kesejahteraan sosial; dan

g. Meningkatkan kesadaran, kemampuan, kepedulian dan tanggung jawab sosial masyarakat dalam penyelenggaraan kesejahteraan, perlindungan anak yatim, anak yatim piatu, dan kaum dhuafa di provinsi secara melembaga dan berkelanjutan.

Kemudian pada BAB III ini berisi hakhak anak yatim yatim piatu dan kaum dhuafa

Pertama: Hak-Hak Anak Yatim dan Anak Yatim Piatu yaitu setiap anak yatim dan anak yatim piatu sampai usia dewasa berhak atas:

a. jaminan kesejahteraan berupa bantuan keuangan, pelayanan pendidikan dan jaminan kesehatan gratis dari Pemerintah Provinsi untuk tumbuh dan berkembang secara wajar.

b. pemeliharaan taraf kesejahteraan dan perlindungan dari lingkungan yang membahayakan dan/atau menghambat pertumbuhan dan perkembangannya secara wajar;

c. pertolongan pertama, bantuan dan perlindungan dalam keadaan yang membahayakan; dan

d. perlindungan terhadap segala bentuk kekerasan fisik dan mental, penelantaran, perlakuan buruk, eksploitasi dan pelecehan seksual, serta hak atas pengasuhan, bimbingan agama, dan mental sosial.
Pasal 7

Dalam hal mendukung hak-hak sebagaimana dimaksud dalam Pasal 5 dan Pasal 6 , setiap orang dilarang :

a. menelantarkan, melakukan tindak kekerasan dan/atau eksploitasi terhadap anak yatim, anak yatim piatu, dan kaum dhuafa;

b. memperkerjakan anak yatim dan anak yatim piatu di bawah usia kerja sebagaimana diatur dalam ketentuan peraturan perundang-undangan yang berlaku;

c. mengekspolitasi atau mengatasnamakan kegiatan dalam bentuk apapun dengan mencantumkan demi kepentingan anak yatim, anak yatim piatu, dan kaum dhuafa, padahal kegiatan tersebut untuk memperoleh kepentingan pribadi atau golongan; dan

d. mengikutsertakan dalam atribut kampanye atau untuk menarik simpatiaan dalam penyelenggaraan pemilihan umum.

Kedua: Pengasuhan dan/atau Pengangkatan

Pasal 8 tentang:

(1) Pemerintah Provinsi dan masyarakat dapat melakukan pengasuhan dan/atau pengangkatan anak yatim dan anak yatim piatu.

(2) Pengasuhan dan/atau pengangkatan dilakukan guna kepentingan peningkatan kesejahteraan anak yatim dan anak yatim piatu

(3) Tata cara dan prosedur pengasuhan dan/ atau pengangkatan sebagaimana dimaksud pada ayat (I) diatur dengan Peraturan Gubernur.

Sedangkan pada BAB IV tertera Tanggung Jawab dan Wewenang. Pada Pasal 9 berisi tentang:

(1) Pemerintah Provinsi bertanggung jawab atas penyelenggaraan perlindungan anak yatim, anak yatim piatu, dan kaum 
dhuafa di Provinsi yang dilaksanakan secara tcrpadu dan berkelanjutan

(2) Penyelenggaraan perlindungan sebagaimana dimaksud pada ayat (1) diperuntukkan kepada anak yatim, anak yatim piatu, dan kaum dhuafa yang berdomisili di Provinsi yang dibuktikan dengan dokumen Akta Kelahiran atau Surat Kenal Lahir yang disahkan oleh Kepala Desa dan Kecamatan.

(3) Penyelenggaraan perlindungan anak yatim, anak yatim piatu, dan kaum dhuafa sebagaimana dimaksud pada ayat (l) meliputi:

a. Pendidikan;

b. Kesehatan;

c. Sosial; dan

d. Perlindungan hukum.

(4) Pelenggaraan perlindungan anak yatim, anak yatim piatu dan kaum dhuafa sebagaimana dimaksud ayat (1), dibebankan kepada Anggaran Pendapatan dan Belanja Daerah.

\section{Pasal 10}

(1) Penyelenggaraan perlindungan anak yatim, anak yatim piatu, dan kaum dhuafa sebagaimana dimaksud dalam Pasal 9 ayat (I), dilaksanakan oleh OPD terkait melalui:
a. Perawatan dan pengasuhan;
b. Pelayanan kesehatan dan perbaikan gizi;
c. Pelayanan pendidikan dan rekreasi;
d. Bimbingan agama, mental dan sosial;
e. Rehabilitasi sosial
f. Bantuan keuangan;
g. Pelayanan administrasi kependu- dukan dan catatan sipil;
h. Pelayanan pemakaman;
i. Pelayanan bantuan hukum;
j. Pemeliharaan taraf kesejahteraan sosial; dan
k. Perlindungan sosial khusus lainnya.

(2) Bagi anak yatim, anak yatim piatu, dan kaum dhuafa yang memiliki keca- catan, selain mendapatkan jaminan kesejahteraan dan perlindungan sebagaimana dimaksud pada ayat (1), juga mendapatkan pelayanan aksesibilitas.

(3) Penyelenggaraan perlindungan anak yatim, anak yatim piatu, dan kaum dhuafa sebagaimana dimaksud pada ayat (1) dapat diselenggarakan oleh masyarakat, organisasi sosial dan dunia usaha.

Pasal 12 ini berisi tentang: Wewenang Pemerintah Provinsi dalam penyelenggaraan perlindungan anak yatim, anak yatim piatu, dan kaum dhuafa dilaksanakan oleh OPD terkait meliputi:

a. Pembuatan perencanaan, pelaksanaan, pengembangan, pembinaan dan pengawasan penyelenggaraan perlindungan anak yatim, anak yatim piatu dan kaum dhuafa;

b. Menyelenggarakan kegiatan kemandirian yang membangun skill/sumber daya manusia anak yatim, anak yatim piatu, dan kaum dhuafa;

c. Penerapan standar pelayanan kesejahteraan sosial;

d. Penyediaan dan/atau pemberian kemudahan serta sarana dan prasarana kepada anak yatim, anak yatim piatu, dan kaum dhuafa;

e. Pemberian kemudahan dalam penyelenggaraan jaminan keaejahteraan dan perlindungan hukum; dan

f. Fasilitas partisipan masyarakat dan/ atau dunia usaha dalam perlindungan anak yatim, anak yatim piatu, dan kaum dhuafa.

Pasal 13

(1) Masyarakat mempunyai kesempatan untuk berperan dalam penyelenggaraan perlindungan anak yatim, anak yatim piatu, dan kaum dhuafa di daerah sebagai tanggung jawab sosial.

(2) Peran masyarakat sebagaimana dimaksud pada ayat (I) dapat dilakukan oleh:
a. Perseorangan
b. Keluarga 
c. Organisasi keagamaan

d. Organisasi sosial kemasyarakatan

e. Lembaga swadaya masyarakat

f. Organisasi profesi

g. Badan usaha

h. Lembaga kesejahteraan sosial; dan

i. Lembaga kesejahteraan sosial asing.

Adapun ketentuan pidana bermanfaat sebagai rambu-rambu sekaligus menjadi efek jera bagi yang melakukannya.

Pasal 16

(1) Setiap orang yang tnelanggar ketentuan sebagaimana dimaksud dalam Pasal 7, diancam dengan pidana kurungan paling lama 6 (enam bulan atau denda paling banyak Rp. 50.000.000.00 (Lima Puluh Juta Rupiah).

(2) Tindak pidana sebagaimana dimaksud pada ayat (1) adalah pelanggaran.

B. Perlindungan Hak Anak Yatim yang Terdapat Dalam Pergub Sumatera Selatan Nomor 6 Tahun 2017 Tentang Penyelenggaraan Perlindungan Anak Yatim Ditinjau dari Maqashid al-Syari'ah

Sesungguhnya yang maha melindungi adalah Allah SWT. Namun secara zhahir melalui kehendak-Nya manusia menjadi salah satu yang berperan untuk menjaga bumi baik yang di darat maupun yang di laut. Melalui penegasan-Nya tentang awal penciptaan manusia yang akan menjadi khalifah (Pemimpin) di dunia ini. Hal tersebut diperkuat dengan diberikan kelebihan kepada manusia dibading makhluk lainnya. Yaitu diberi akal dan nafsu. Di samping itu penganugerahan kehidupan Allah SWT tidak pernah melihat suku ras, jenis kelamin, bangsa maupun agama. Hal ini Sesuai dengan Sabda Nabi Muhammad SAW yang diriwayatkan dari Amr bin Ash. Bahwasanya Rasulullah SAW bersabda: (an-Nasai, TT).

$$
\text { ون فتل رجلا من أهل النمة لم يجد ريح الجنة }
$$

Artinya: "Barang siapa yang membunuh seorang kafir dzimmi, maka dia tidak akan mencium bau surga. Padahal sesungguhnya bau surga itu tercium dari perjalanan empat puluh tahun." (HR. An-Nasa'i yang bersumber Amr bin Ash)".

Diantara hak manusia yang paling dikedepankan oleh islam adalah hak untuk hidup dan menghargai hidup (nyawa) orang lain. Allah SWT mengemukakan secara lugas dalam Q.S al-Maidah ayat 32 yaitu :

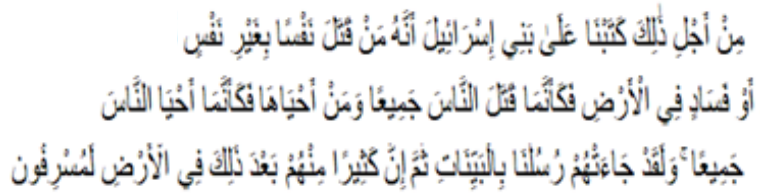

Artinya: "Oleh Karena itu kami tetapkan (suatu hukum) bagi Bani Israil, bahwa:barangsiapa yang membunuh seorang manusia, bukan Karena orang itu (membunuh) orang lain, atau bukan Karena membuat kerusakan dimuka bumi, Maka seakan-akan dia Telah membunuh manusia seluruhnya. Dan barangsiapa yang memelihara kehidupan seorang manusia, Maka seolah-olah dia Telah memelihara kehidupan manusia semuanya. dan Sesungguhnya Telah datang kepada mereka rasul-rasul kami dengan (membawa) keterangan-keterangan yang jelas, Kemudian banyak diantara mereka sesudah itu sungguhsungguh melampaui batas dalam berbuat kerusakan dimuka bumi"

Ayat di atas menjelaskan ketentuan bahwa membunuh seorang manusia berarti membunuh semua manusia, sebagaimana memelihara kehidupan seorang manusia berarti memelihara kehidupan semua manusia. Islam tidak memhalalkan darah orang lain bukan saja darah seorang muslim bahkan non muslim pun tidak halal darahnya selama tidak memerangi kaum muslimin. Rasulullah bersabda :

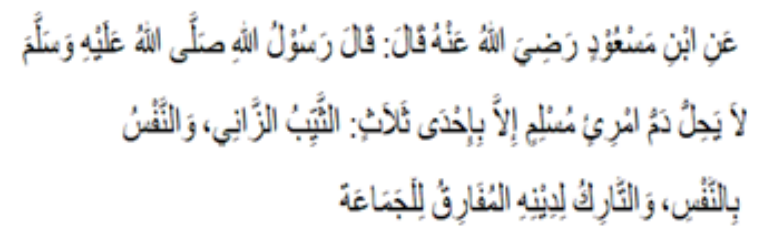


Dari Ibnu Mas'ud radhiyallahu 'anhu, ia berkata, "Rasulullah shallallahu 'alaihi wa sallambersabda, "Tidak halal darah seorang muslim kecuali karena salah satu dari tiga sebab: (1) orang yang telah menikah yang berzina, (2) jiwa dengan jiwa (membunuh), (3) orang yang meninggalkan agamanya (murtad), lagi memisahkan diri dari jamaah kaum muslimin." (HR. Bukhari dan Muslim) (HR. Bukhari dan Muslim) [HR. Bukhari, no. 6878 dan Muslim, no. 1676].

Memang di dalam islam terdapat hukum Qishas (balas) sebagai bentuk keadilan dari Allah SAW namun diujung penjelasan ayat tentang Qishas tersebut Allah SAW masih memberikan tawaran jika ahli waris memaafkan jauh lebih baik. kemudian Ayat ini sekaligus memberikan petunjuk bagi seluruh manusia agar tetap menjaga lingkungan dan hal berbahaya lainnya yang dapat menggangu kehidupan bersama.

Dalam Maqashid al-Syariah menurut alSyatibi ada lima tujuan pokok syariat Islam, yaitu dalam rangka melindungi agama, jiwa, akal, keturunan dan harta. Kelima pokok tersebut dinamakan dengan al-kulliyah alkhams atau al-qowaid al-kulliyat. Adapun makna Maqasid al-Syariah ialah tujuan alsyari' (Allah SWT dan Rasulullah SAW). Dalam menetapkan hukum Islam. Tujuan tersebut dapat ditelusuri dari Nash Alqur'an dan Sunnah Rasulullah SAW, sebagai alasan logis bagi rumusan suatu hukum yang berorientasi kepada kemaslahatan umat manusia. (Mardhani, 2013).

Menurut al-Syatibi ada lima tujuan pokok syariat Islam, yaitu dalam rangka melindungi agama, jiwa, akal, keturunan dan harta. Kelima pokok tersebut dinamakan dengan al-kulliyah al-khams atau al-qowaid al- kulliyat. Untuk kepentingan menetapkan hukum, kelima tujuan pokok tersebut dikategorikan menjadi tiga tingkatan, yaitu: (Mardhani, 2013).

1. Dharuri, yaitu Menjaga kebutuhan yang bersifat primer bagi kelangsungan hidup manusia, Kebutuhan primer ter- sebut adalah Hifz Din (memelihara agama), Hifz Nafs (Memelihara jiwa, Hifz aql (Memelihara akal), Hifz Nasl (Memelihara Keturunan), dan Hifz Mal (Memelihara Harta). Kelima tujuan pokok tersebut harus dipastikan aman setiap manusia. Sehingga dengan demikian akan tercipta nuansa manusia yang serba berkecukupan dan terpenuhi hak-haknya sebagai manusia. Datangnya syariat islam menjadi indikator terpeliharanya lima hal pokok tersebut. Apabila kita mencoba meneliti sebuah ayat tentunya akan ditemukan alasan-alasan kenapa sebuah syariat itu diperintahkan untuk dikerjakan. Puncak akhir dari sebuah penelitian tersebut akan bermuara pada pemeliharaan lima hal pokok di atas. Salah satu contohnya adalah tentang Qishas (balas). Syariat tentang kewajiban melaksanakan qishas dapat di temukan dalam firman Allah pada Q.S al- Baqarah (2) ayat 179:

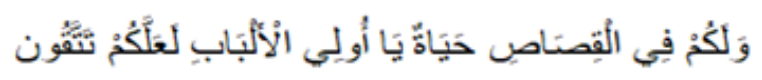

Artinya: "Dan dalam qishaash itu ada (jaminan kelangsungan) hidup bagimu, Hai orang-orang yang berakal, supaya kamu bertakwa". (Departemen Agama RI, 2010).

2. Hajiyat, yaitu kebutuhan yang tidak bersifat Pokok. Kebutuhan yang sifatnya hajiyah tidak sampai menghilangkan hidupnya kecuali kebutuhan yang dapat menjauhkan manusia dari kesulitan dalam hidupnya. Meskipun kebutuhan hajiyat ini tidak terpenuhi tidak akan mengancam kelangsungan kelima pokok di atas, melainkan hanya akan menimbulkan kesulitan bagi mukallaf. Biasanya kelompok ini selalu ada keringanan (Rukhsah). Seperti halnya yang telah dikemukakan oleh Abdul Wahab Khallafbahwa kebutuhan ini merupakan contoh kepedulian syariat Islam saja. Contoh pembolehan tidak berpuasa bagi 
seorang yang sedang dalam perjalanan atau musafir, Wanita hamil, wanita menyusui yang apabila memaksakan pelaksanaan syariat tersebut akan berakibat fatal bagi seorang ibu atau anak yang disusui. Contoh lain seperti seorang yang hanya membayar diyat atau denda karena terlibat dalam pembunuhan yang tidak disengaja atau direncanakan. Dan juga penangguhan potong tangan bagi seorang yang ingin menyelamatkan jiwanya karena kelaparan dan akhirnya mencuri barang milik orang lain.

3. Tahsiniyat, yaitu kebutuhan yang sifatnya pelengkap. Kegunannaya adalah untuk menunjang peningkatan martabat seseorang dalam masyarakat dan dihadapan Tuhan-nya sesuai dengan kepatuhan. Kelompok yang ketiga ini adalah sebagai bahan pelengkap kebutuhan. Imam al-Syatibi mengemukakan atas dasar kepatutan. Hal ini lebih kepada sosial masyarakat dan budaya adat istiadat yang berkembang ditempat itu. Bisa saja dalam hal kepatutan terdapat perbedaan antara tempat yang satu dengan yang lainnya. Seperti tidak terlalu mencolok dalam berpakaian dan berhias yang intinya sesuai dengan kepatutan menurut adat-istiadat dengan tuntutan norma dan akhlak, dalam berbagai bidang kehidupan seperti ibadah muamalah dan 'uqubah.

Maqashid al-Syariah memandang anak yatim mempunyai hak yang sama dengan orang yang bukan anak yatim dalam mendapatkan haknya, baik saat di dunia dan di akhirat. Misalnya dalam hal perlindungan anak. Islam mengenal konsep hadhanah yang wajib dilakukan bagi setiap keluarga. (Hadi, 206).

Maqasid al-Syariah adalah upaya untuk mewujudkan kemaslahatan dan menghindarkan keburukan atau menarik manfaat dan menolak mudarat. Dengan berbagai perlindungan yang diberikan Islam maka dapat dipahami bahwa perlindungan yang diberikan kepada setiap umat manusia bertujuan untuk kemaslahatan setiap manusia termasuk anak yatim. Dalam al-Qur'an terdapat beberapa ayat yang berkaitan dengan anak yatim. Kalau ayat-ayat tersebut dicermati dengan baik maka semua menyinggung tentang jangkauan perlindungan anak yatim yang tertuang di dalam pergub nomor 6 tahun 2017. Berkut ayat-ayat yang menjelaskan tentang hakhak anak yatim:

Ayat-ayat al-Qur'an tentang anak yatim

1. QS. al-An'an ayat 152:

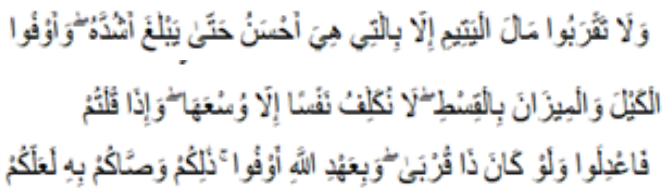

Artinya: "Dan janganlah kamu dekati harta anak yatim, kecuali dengan cara yang lebih bermanfaat, hingga sampai ia dewasa. Dan sempurnakanlah takaran dan timbangan dengan adil. Kami tidak memikulkan beban kepada sesorang melainkan sekedar kesanggupannya. Dan apabila kamu berkata, maka hendaklah kamu berlaku adil, kendatipun ia adalah kerabat(mu), dan penuhilah janji Allah. Yang demikian itu diperintahkan Allah kepadamu agar kamu ingat."

2. Qs. al-Isra ayat 34 :

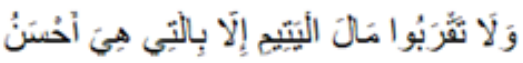

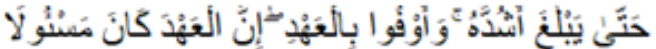

Artinya: "Dan janganlah kamu mendekati harta anak yatim, kecuali dengan cara yang lebih baik (bermanfaat) sampai ia dewasa dan penuhilah janji; sesungguhnya janji itu pasti diminta pertanggungan jawabnya".

3. QS. al-Fajr ayat 17,

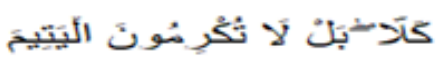

Artinya: "Sekali-kali tidak (demikian), sebenarnya kamu tidak memuliakan anak yati".

4. QS. ad-Duha ayat 6 dan 9, :

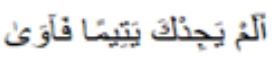

Artinya: "Bukankah Dia mendapatimu sebagai seorang yatim, lalu Dia melindungimu" (adDuha ayat 6) 


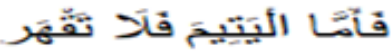

Artinya: "Sebab itu, terhadap anak yatim janganlah kamu berlaku sewenang-wenang". (ad-dhuha ayat 9)

5. QS. al-Maun ayat 2,

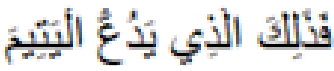

Artinya: "Itulah orang yang menghardik anak yatim".

6. QS. al-Insan ayat 8,

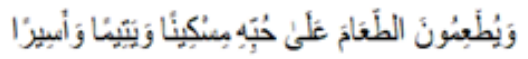

Artinya: "Dan mereka memberikan makanan yang disukainya kepada orang miskin, anak yatim dan orang yang ditawan”.

7. QS. al-Balad ayat 15,

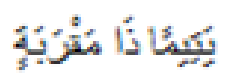

Artinya: "(kepada) anak yatim yang ada hubungan kerabat".

8. QS. al-Kahfi ayat 82,

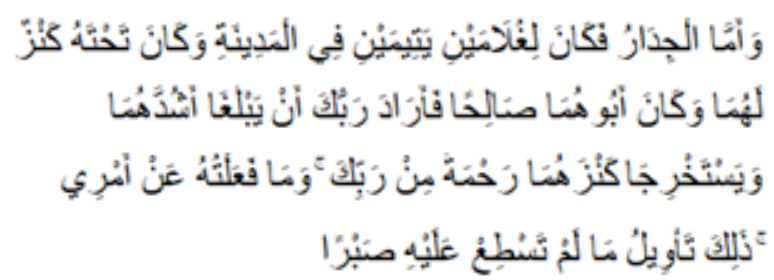

Artinya: "Adapun dinding rumah adalah kepunyaan dua orang anak yatim di kota itu, dan di bawahnya ada harta benda simpanan bagi mereka berdua, sedang ayahnya adalah seorang yang saleh, maka Tuhanmu menghendaki agar supaya mereka sampai kepada kedewasaannya dan mengeluarkan simpanannya itu, sebagai rahmat dari Tuhanmu; dan bukanlah aku melakukannya itu menurut kemauanku sendiri. Demikian itu adalah tujuan perbuatan-perbuatan yang kamu tidak dapat sabar terhadapnya".

9. QS. al-baqarah ayat 83,

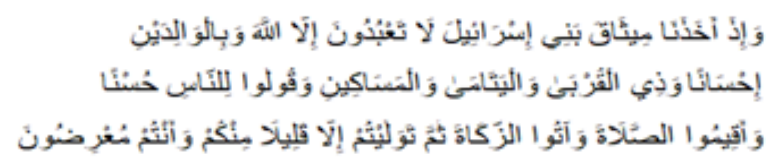

Artinya: "Dan (ingatlah), ketika Kami mengambil janji dari Bani Israil (yaitu): Janganlah kamu menyembah selain Allah, dan berbuat kebaikanlah kepada ibu bapa, kaum kerabat, anak-anak yatim, dan orang-orang miskin, serta ucapkanlah kata-kata yang baik kepada manusia, dirikanlah shalat dan tunaikanlah zakat. Kemudian kamu tidak memenuhi janji itu, kecuali sebahagian kecil daripada kamu, dan kamu selalu berpaling".

10. QS. al-Baqarah ayat 177

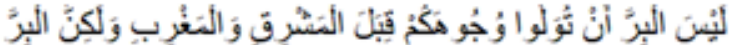

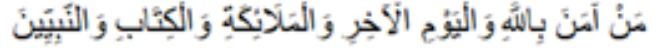

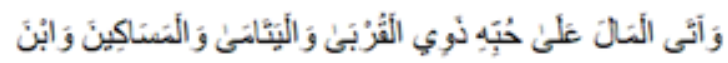

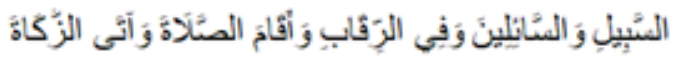

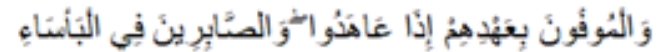

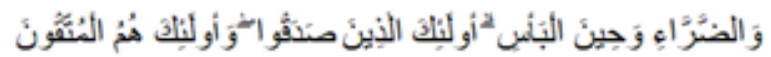

Artinya: "Bukanlah menghadapkan wajahmu ke arah timur dan barat itu suatu kebajikan, akan tetapi sesungguhnya kebajikan itu ialah beriman kepada Allah, hari kemudian, malaikat-malaikat, kitab-kitab, nabi-nabi dan memberikan harta yang dicintainya kepada kerabatnya, anak-anak yatim, orangorang miskin, musafir (yang memerlukan pertolongan) dan orang-orang yang memintaminta; dan (memerdekakan) hamba sahaya, mendirikan shalat, dan menunaikan zakat; dan orang-orang yang menepati janjinya apabila ia berjanji, dan orang-orang yang sabar dalam kesempitan, penderitaan dan dalam peperangan. Mereka itulah orang-orang yang benar (imannya); dan mereka itulah orangorang yang bertakwa".

11. QS. Al-baqarah ayat 215

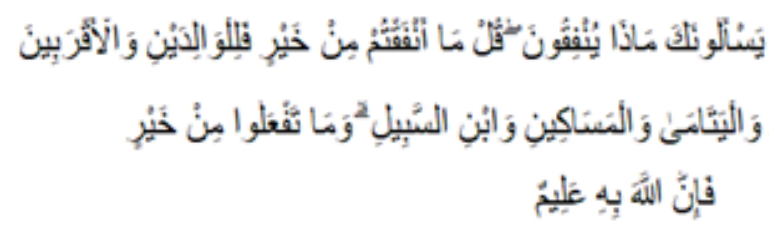

Artinya: "Mereka bertanya tentang apa yang mereka nafkahkan. Jawablah: "Apa saja harta yang kamu nafkahkan hendaklah diberikan kepada ibu-bapak, kaum kerabat, anakanak yatim, orang-orang miskin dan orangorang yang sedang dalam perjalanan". Dan apa saja kebaikan yang kamu buat, maka 
sesungguhnya Allah Maha Mengetahuinya”.

Al-baqarah ayat 220 :

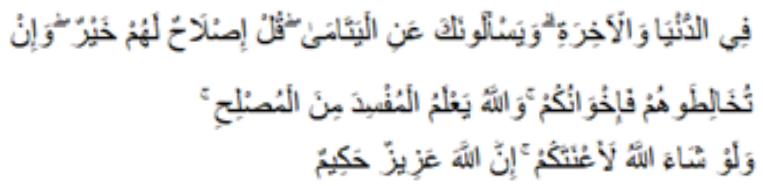

Artinya: "tentang dunia dan akhirat. Dan mereka bertanya kepadamu tentang anak yatim, katakalah: "Mengurus urusan mereka secara patut adalah baik, dan jika kamu bergaul dengan mereka, maka mereka adalah saudaramu; dan Allah mengetahui siapa yang membuat kerusakan dari yang mengadakan perbaikan. Dan jikalau Allah menghendaki, niscaya Dia dapat mendatangkan kesulitan kepadamu. Sesungguhnya Allah Maha Perkasa lagi Maha Bijaksana".

12. QS. an-Nisa' ayat 2:

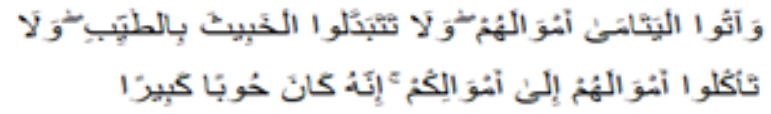

Artinya: "Dan berikanlah kepada anakanak yatim (yang sudah balig) harta mereka, jangan kamu menukar yang baik dengan yang buruk dan jangan kamu makan harta mereka bersama hartamu. Sesungguhnya tindakantindakan (menukar dan memakan) itu, adalah dosa yang besar."

13. QS. an-Nisa ayat 1

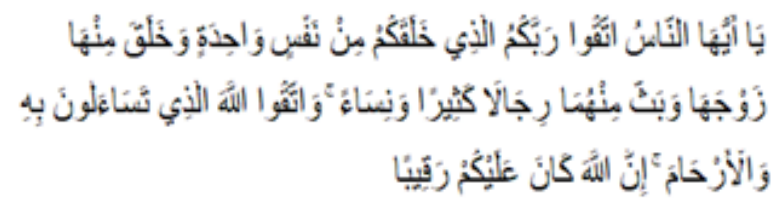

Artinya: "Hai sekalian manusia, bertakwalah kepada Tuhan-mu yang telah menciptakan kamu dari seorang diri, dan dari padanya Allah menciptakan isterinya; dan dari pada keduanya Allah memperkembang biakkan laki-laki dan perempuan yang banyak. Dan bertakwalah kepada Allah yang dengan (mempergunakan) nama-Nya kamu saling meminta satu sama lain, dan (peliharalah) hubungan silaturrahim. Sesungguhnya Allah selalu menjaga dan mengawasi kamu".
14. QS. an-Nisa' ayat 3

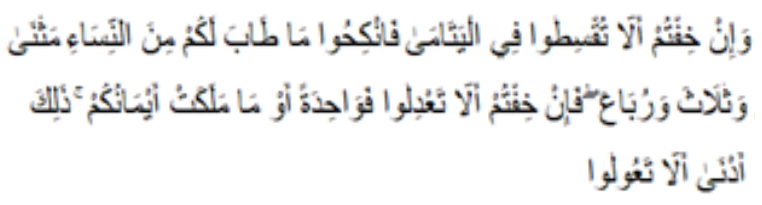

Artinya: "Dan jika kamu takut tidak akan dapat berlaku adil terhadap (hak-hak) perempuan yang yatim (bilamana kamu mengawininya), maka kawinilah wanita-wanita (lain) yang kamu senangi: dua, tiga atau empat. Kemudian jika kamu takut tidak akan dapat berlaku adil, maka (kawinilah) seorang saja, atau budak-budak yang kamu miliki. Yang demikian itu adalah lebih dekat kepada tidak berbuat aniaya".

15. QS. an-Nisa' ayat 6

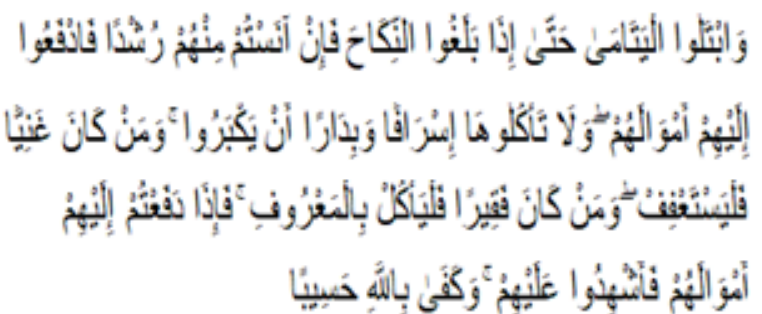

Artinya: "Dan ujilah anak yatim itu sampai mereka cukup umur untuk kawin. Kemudian jika menurut pendapatmu mereka telah cerdas (pandai memelihara harta), maka serahkanlah kepada mereka harta-hartanya. Dan janganlah kamu makan harta anak yatim lebih dari batas kepatutan dan (janganlah kamu) tergesa-gesa (membelanjakannya) sebelum mereka dewasa. Barang siapa (di antara pemelihara itu) mampu, maka hendaklah ia menahan diri (dari memakan harta anak yatim itu) dan barangsiapa yang miskin, maka bolehlah ia makan harta itu menurut yang patut. Kemudian apabila kamu menyerahkan harta kepada mereka, maka hendaklah kamu adakan saksi-saksi (tentang penyerahan itu) bagi mereka. Dan cukuplah Allah sebagai Pengawas (atas persaksian itu)"

16. QS. an-Nisa' ayat 8

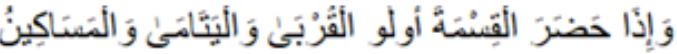

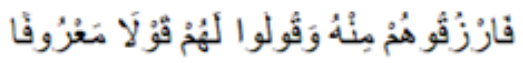


Artinya: "Dan apabila sewaktu pembagian itu hadir kerabat, anak yatim dan orang miskin, maka berilah mereka dari harta itu (sekedarnya) dan ucapkanlah kepada mereka perkataan yang baik".

17. QS. an-Nisa' ayat 10

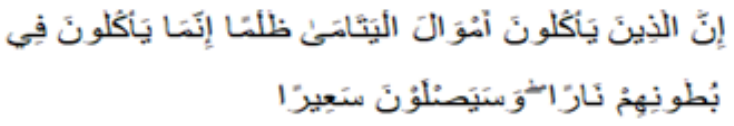

Artinya: "Sesungguhnya orang-orang yang memakan harta anak yatim secara zalim, sebenarnya mereka itu menelan api sepenuh perutnya dan mereka akan masuk ke dalam api yang menyala-nyala (neraka)".

18. QS. an-Nisa' ayat 36

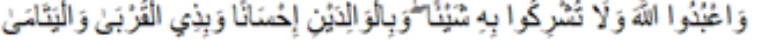

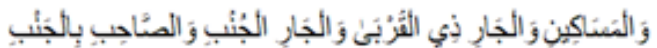

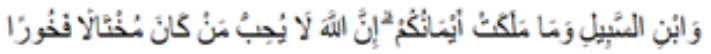

Artinya : "Sembahlah Allah dan janganlah kamu mempersekutukan-Nya dengan sesuatupun. Dan berbuat baiklah kepada dua orang ibu-bapa, karib-kerabat, anak-anak yatim, orang-orang miskin, tetangga yang dekat dan tetangga yang jauh, dan teman sejawat, ibnu sabil dan hamba sahayamu. Sesungguhnya Allah tidak menyukai orang-orang yang sombong dan membangga-banggakan diri”.

19. QS. an-Nisa' ayat 127

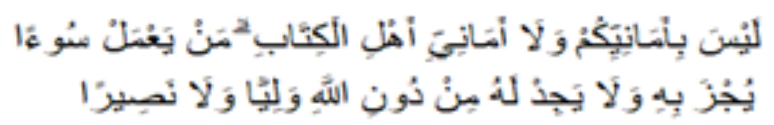

Artinya: "(Pahala dari Allah) itu bukanlah menurut angan-anganmu yang kosong dan tidak (pula) menurut angan-angan Ahli Kitab. Barangsiapa yang mengerjakan kejahatan, niscaya akan diberi pembalasan dengan kejahatan itu dan ia tidak mendapat pelindung dan tidak (pula) penolong baginya selain dari Allah".

20. al-Anfal ayat 41

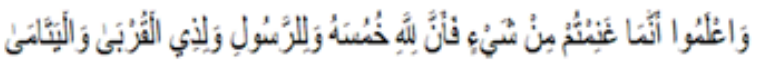

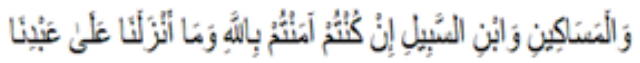

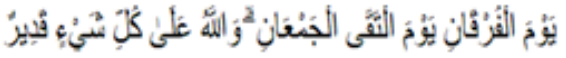

Artinya: "Ketahuilah, sesungguhnya apa saja yang dapat kamu peroleh sebagai rampasan perang, maka sesungguhnya seperlima untuk Allah, Rasul, kerabat Rasul, anak-anak yatim, orang-orang miskin dan ibnussabil, jika kamu beriman kepada Allah dan kepada apa yang kami turunkan kepada hamba Kami (Muhammad) di hari Furqaan, yaitu di hari bertemunya dua pasukan. Dan Allah Maha Kuasa atas segala sesuatu".

21. QS. al-Hasyr ayat 7

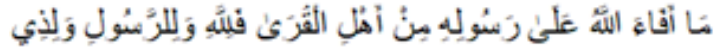

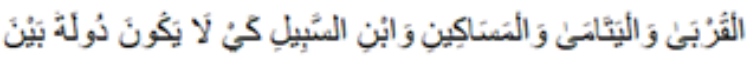

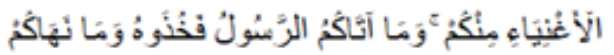

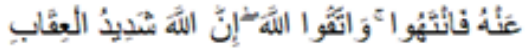

Artinya: "Apa saja harta rampasan (fai-i) yang diberikan Allah kepada Rasul-Nya (dari harta benda) yang berasal dari penduduk kota-kota maka adalah untuk Allah, untuk Rasul, kaum kerabat, anak-anak yatim, orangorang miskin dan orang-orang yang dalam perjalanan, supaya harta itu jangan beredar di antara orang-orang kaya saja di antara kamu. Apa yang diberikan Rasul kepadamu, maka terimalah. Dan apa yang dilarangnya bagimu, maka tinggalkanlah. Dan bertakwalah kepada Allah. Sesungguhnya Allah amat keras hukumannya".

Dari sejumlah ayat di atas terdapat satu kesimpulan betapa Allah SAW memperhatikan tentang nasib anak yatim, mulai dari agamanya, jiwanya, akalnya, keturunannya, dan hartanya. Seperti pada QS. al-Baqarah ayat 83 di atas kemaslahatan itu dapat diwujudkan apabila semua unsur yang lima dapat berjalan dengan baik. Seperti pada BAB III dalam PERGUB tersebut berisi hak-hak anak yatim yatim piatu dan kaum dhuafa.

Pertama : Hak-Hak Anak Yatim dan Anak Yatim Piatu yaitu Setiap anak yatim dan anak yatim piatu sampai usia dewasa berhak atas:

a. Jaminan kesejahteman berupa bantuan keuangan, pelayanan pendidikan dan jaminan kesehatan gratis dari Pemerintah Provinsi untuk tumbuh dan berkembang secara wajar.

b. Pemeliharaan taraf kesejahtaraan dan per- 
lindungan dari lingkungan yang membahayakan dan/atau menghambat pertumbuhan dan perkembangannya secara wajar.

c. Pertolongan pertama, bantuan dan perlindungan dalam keadaan yang membahayakan; dan

d. Perlindungan terhadap segala bentuk kekerasan fisik dan mental, penelantaran, perlakuan buruk, eksploitasi dan pelecehan seksual, serta hak atas pengasuhan, bimbingan agama, dan mental sosial.

Kemudian Pasal 7 berisi hal-hal yang dilarang yaitu: Dalam hal mendukung hak-hak sebagaimana dimaksud dalam Pasal 5 dan Pasal 6, setiap orang dilarang:

a. Menelantarkan, melakukan tindak kekerasan dan/atau eksploitasi terhadap anak yatim, anak yatim piatu, dan kaum dhuafa.

b. Memperkerjakan anak yatim dan anak yatim piatu di bawah usia kerja sebagaimana diatur dalam ketentuan peraturan perundang-undangan yang berlaku.

c. Mengeksploitasi atau mengatasnamakan kegiatan dalam bentuk apapun dengan mencantumkan demi kepentingan anak yatim, anak yatim piatu, dan kaum dhuafa, padahal kegiatan tersebut untuk memperoleh kepentingan pribadi atau golongan; dan

d. Mengikutsertakan dalam atribut kampanye atau untuk menarik simpatisan dalam penyelenggaraan pemilihan umum.

Pada Pasal 16 berisi tentang sanksi yang akan didapatkan oleh seseorang manakala melakukan yang dilarang dan melanggar yang diamanatkan dalam PERGUB tersebut. Ketentuannya sebagaimana dalam pasal 7 diancam pidana kurungan paling lama 6 (enam) bulan atau denda Rp.50.000.000.00 (Lima Puluh Juta Rupiah). (SumSel, 2017). Ini salah satu peraturan prefentif dimana sebelum orang melakukan hal yang salah terhadap anak yatim terlebih dahulu mengetahui akibatnya.

Menurut ajaran islam terdapat banyak cara untuk menyelamatkan hidup manusia dari ancaman kematian. Apabila seorang muslim menderita sakit, Menderita luka-luka atau terkena musibah, maka yang demikian menjadi tanggung jawab bagi saudara yang lain untuk menolongnya memperoleh bantuan medis. Dan apabila ia terancam kelaparan, maka saudara sesama muslim berkewajiban memberikan makanan. Setelah penulis menganalisa PERGUB Sumatera Selatan Nomor 6 Tahun 2017 Tentang Perlindungan Anak yatim benar terdapat benar terdapat hal memelihara Jiwa (hifzh an-nafs) sebagaimana yang terkandung pada tujuan Maqashid asySyariah. Keterpenuhan tersebut meliputi tingkat dharuriyah seperti memenuhi kebutuhan pokok berupa makanan untuk mempertahankan hidup. Ini merupakan hak yang tidak boleh tidak demi kelangsungan hidup anak yatim. Kemudian tingkat hajiyat seperti dibolehkannya anak yatim untuk mengikuti pendidikan, bergaul dengan teman yang lainnya tanpa membedakan apakah ia anak yatim atau bukan. Adapun jika kebutuhan hajiyat-nya tidak terpenuhi maka tidak sampai mengancam eksistensi manusia, melainkan hanya mempersulit hidupnya dan tingkat tahsiniyat, seperti ditetapkan tata cara dan sopan santun ketika makan dan minum.

\section{SIMPULAN}

Penyelenggaraan Perlindungan jiwa dalam PERGUB SUMSEL No 6 tahun 2017 tentang perlindungan anak yatim terdapat pada pasal 4 . Pada pasal 5 mengatur tentang hak-hak hidup bagi anak yatim, selanjutnya dalam hal mendukung pemberian hak-hak anak yatim maka pada pasal 7 diuraikan hal-hal yang dilarang terhadap anak yatim. Kemudian tentang apa saja yang menjadi tanggung jawab dan wewenang Pemda tertuang pada pasal 9 yaitu pendidikan kesehatan sosial dan perlindungan hukum. Seterusnya ketentuan sumber dana dan ketentuan pidana bagi siapa saja yang melanggar ketentuan yang berlaku terdapat pada pasal 14 dan 16. Setiap orang yang menghalang-halangi dan/atau melarang penyandang disabilitas untuk mendapatkan haknya dipidana dengan penjara paling lama (6) bulan dan denda paling banyak Rp.50.000.000,00 (Lima Puluh Juta Rupiah).

Sebagai agama yang rahmatan lil alamin, Islam telah memberikan petunjuk tentang cara 
untuk membantu hidup manusia memelihara jiwa. Seseorang yang menderita sakit, menderita luka-luka atau terkena musibah, maka hal tersebut menjadi tanggung jawab bagi kerabat yang lain untuk membantunya mendapatkan bantuan pengobatan. Jika ternyata seseorang yang terancam kelaparan tidak memiliki kerabat dekat maka kewajiban beralih kepada kaum muslimin yang lainnya. Dalam Pergub Sumsel No 6 Tahun 2017 ini benar-benar jiwa anak yatim akan terpelihara dengan baik karena jika kerabat dekat dan jauh pun tidak pemerntah daerah dari bagian kesejahteraan siap membantu melindungi jiwa anak yatim, pendidikan, kesehatan, sosial dan perlindungan hukum. Dengan demikian tujuan Maqahid asy-Syariah dalam memelihara Jiwa (hifz an-nafs) dapat terpenuhi. Baik tingkat dharuriyah, Hajiyat, dan Tahsiniyat. Dalam hal menghindari sesuatu yang tidak diinginkan terjadi kepada anak yatim maka disarankan agar ahli waris, kerabat dekat, kaum muslimin dan pemerintah dapat bersinergi dalam menyelenggarakan perlindungan kepada anak yatim. Karena jika tidak maka hak-hak anak yatim akan terabaikan dan itu adalah dosa bagi ahli waris, kerabat dekat, kaum muslimin dan bahkan pemerintah daerah setempat.

\section{PENGHARGAAN}

Rasa syukur yang tiada terhingga saya haturkan kepada Allah SWT, Dialah Tuhan yang memberikan nikmat kesehatan dan kesempatan demi terwujudnya penulisan artikel ini. Jurnal ilmiah ini diselesaikan dan dibiayai oleh saya sendiri. Pada ucapan penghargaan ini saya ingin saya ingin mengucapkan terimakasih banyak kepada keluarga yang selalu mendukung untuk menyelesaikan tulisan ini. Kemudian terimakasih saya juga kepada rekan-rekan yang terlibat secara langsung maupun tidak dalam menjawab setiap persoalan-persoalan yang saya utarakan demi kesempurnaan penelitian ini.

\section{DAFTAR PUSTAKA}

A.Dzajuli, A. (2003). Fiqh Siyasah. Bandung: Pranada Media.
al-Qardhawi, Y. (1999). Fikih Praktis Bagi kehidupan Modern.Cairo: Maktabah Wahbah. Al-Zamakhsharī, A.-Z. (TT). al-Kasysyaf. Beirut: Daar al_Kutub al-Arabiyah.

an-Nasai, a.-N. (TT). Sunan as-Sughra Li anNasai. Maktabah Matbu'ah al-Islamiyah.

Ansori, A., \& Harahap, Y. (2008). Hukum Islam Dinamika dan Perkembangannya di Indonesia. Yogyakarta: Kreasi Media.

as-Syatiby, A. (TT). al-Muwafaqot Fi Ushul alSyari'ah. Beirut: Daar al-Ma'rifah.

az-Zuhaily, W. (1997). Ilmu Ushul Fiqh. Cairo: Daar al-Ma'arif.

b. Abī Bakr al-Rāzī, M. (1931). Mukhtar Al-Sihah. Beirut: Daar Al-Fikr.

Bin Zakariya, A. A. (TT). Mu'jam Maqayish alLughah.

Departemen Agama RI, D. (2010). al-Quran dan Tafsirnya. Jakarta: Lentera Abadi.

Efendi, S. (2005). Ushul Fiqh. Jakarta: PRENADA MEDIA GROUP.

Ghosita, A. (1989). Masalah Perlindungan Anak. Jakarta: Akadanih.

Hadi, M. (206). Fikih Anak Yatim Studi Tentang Hukum Islam Berbasis Maslahah. Palastren, 4-5.

Ibnu Manzhur, M. B. (1993). Lisan Arab. Beirut: Daar Kutub al-Ilmiyah.

lihasanah, A. (TT). al-Fiqh al-Maqashid Inda alImam as-Syatiby.

Mardhani. (2013). Ushul Fiqh. Jakarta: PT. RAJAGRAPINDO PERSADA.

Rahman, A. (1993). Syari'ah Kodifikasi Hukum Islam. Jakarta: Rineka Cipta.

Sum-Sel, P. (2017). Penyelenggaraan Perlindungan Anak Yatim. Sumatera Selatan.

Syahputra, W. (2014, 02 24). Republika.co.id. Retrieved 02 24, 2014, from Republika.co.id: https://www.republika.co.id/berita/nasional/ umum/14/02/24/n1hnml-polisi-dalamidugaan-penyiksaan-anak-di-panti-asuhan

Umar, H. (2007). Nalar Fikih Kontemporer. Jakarta: Gaung Persada press.

Yunus, M. (1990). Kamus Arab-Indonesia. Jakarta: PT. Mahmud Yunus al-Wardzuriyah. 